\title{
The entry of women in predominantly male professions: when training supports the search of alternative ways of organizing work time
}

\author{
Sónia Nogueira ${ }^{\mathrm{a}}, *$, Marianne Lacomblez ${ }^{\mathrm{a}}$, Marta Santos ${ }^{\mathrm{a}}$, Liliana Cunha ${ }^{\mathrm{a}, \mathrm{b}}$ and Joana Castelhano ${ }^{\mathrm{a}}$ \\ ${ }^{a}$ Centro de Psicologia da Universidade do Porto, Universidade do Porto, Rua Alfredo Allen, 4200-135 Porto, \\ Portugal \\ ${ }^{b}$ Universidade Católica Portuguesa, Rua Diogo Botelho 1327, 4169-005 Porto, Portugal
}

\begin{abstract}
Following a research carried out on the integration of women in professional areas predominantly for men, this paper intends to present and debate the project of a training course which aims the transformation of the organization of work schedules in order to improve the well-being of the workers involved. The conception of training courses with this type of objective involves the confrontation and debate between the "invested skills" of the trainers and the "constituted skills" of the trainees. But will this paradigm remain intact when applied to training courses permeated by the gender dimension? That is what one will try to realize with the effective implementation of a training course, whose reflection will allow, ultimately, to enrich our understanding on gender, work, health and training.
\end{abstract}

Keywords: Training, gender, motives, health, paradigms

\section{Introduction}

Ergonomics has as its objective the transformation of and the improvement of the conditions in which it is performed that prevails over the training of the individuals [5]. To combine this objective with continuous training requires confronting a number of technical, methodological and pragmatic challenges, which support a specific understanding of training in this field.

This conception was first established by Laville and Teiger when they defined intervention models within a new praxis [5] based on another conceptualization of the relationship between knowledge and action:

- Resorting to a Piagetian constructivist perspective - according to which all and any knowledge does not consist of being capable to copy the real, but of acting on it and transforming it, into appearance or reality, in order to understand it $[8,9]$ - supported a project to conceive training of the developmental type, so that the workers can perform appropriately in the improvement of their working conditions and, at the same time, in their self-development;

- The analysis of the work activities drew attention to the unavoidable nature of recognition of the skills built by experience; their improvement requires discussion, constantly updated, with the trainers, taking on a decisive role in the integration of the different approaches.

In the scope of this perspective, the EAWT symposiums (see namely Lacomblez, Bellemare, Chatigny, Delgoulet, Re, Trudel \& Vasconcelos [4]) continuously organized in the IEA Congresses showed that a training course does not gain from being prescriptive, since the theoretical and abstract nature of

${ }^{*}$ Corresponding author: snogueira@fpce.up.pt 
the skills considered at the time, rarely articulate with the reality in which the trainees later find themselves, and fulfill the intended meaning. A training course is, therefore, enriched: by articulation with the reality of a work activity which is known to the trainees; and by alternating moments of data collection related to concrete work situations and moments for reflection on such data. The progress of the participants in the training course will thus run as a result of the conjugation of two types of skills, which complement each other: the "invested skills" of the workers; and the "constituted skills" of the researchers [13].

However, studies carried out having this reading grid as a basis $[11 ; 12]$, enriched by Vygotski's work [18], drew attention to mediation, in the learning process, of the "motives" that support the continuity of the trainees participation: the acquisition of new skills always seems to be considered based on the pertinence of the skills already acquired and historically and socially produced.

\section{A training course on organization of work schedules}

Based on these assumptions, the central issue of this proposal is related to the development of a continuous training course, articulated on the basis of what a work activity ends up requiring due to the implementation of certain models, criteria and values in the management of the work schedules.

As follow-up of a research recently carried out on the integration of women in professional areas predominantly for men [3], this training course intends to consider that "time constitutes one of the keypoints for equality between men and women, a major explanatory factor of the sex differences" [14]. It seems, in effect, that many apparent gender inequalities are related to the sexual use of time, both in the professional and private sphere - even because the change (not always voluntary) to a part-time schedule may express, in women, a symmetric increase of domestic and family work.

Well, we state that, before the Anglo-Saxon concept of work-life balance, supported by the analysis of individual efforts, which will allow the best coordination possible between work requirements and those of personal life, it is important not to neglect the changes in work organization - by focusing the attention on the family factors, we could forget that the perspective of conciliation equally questions the methods for the management of workers. Consequently, the purpose of a training course related to the management of the work schedules cannot "make use of one eye only" [6], not even if, in this matter, the gender becomes a non- issue [15].

However, what has to be constructed and what shall be constructed in this training about the organization of working hours when the dimension gender is assumed?

Two different lines of research are being considered, involving and questioning paradigms which until today have predominated in our scientific community.

\section{Questioning paradigms}

The "constituted skills" brought up in this type of training course obviously refer to the theoretical and methodological framework supplied by the scientific tradition of the ergonomics of the activity, accessible through the amount of literature available on the subject of atypical work schedules and their effects on health and "well-being" (see namely $[1,10,16]$ ). This is, however, an approach defined with a "model of gender neutrality of the "workers» where the implicit reference is the male worker" [17].

The work prior to the training has, therefore, to cross the matrix of this paradigm with the most recent studies, which show professional marginalization processes (not rarely associated with deterioration of health), namely of the women when they can not cope with the almost unconditional availability requirements in the context of stagnation - and, sometimes, of an inversion - of the process of reduction in the annual duration of the work [7], and of a more frequent use of the variable schedules, night and weekend work.

Studies carried out in Brazil are in agreement with these observations, highlighting however the nondichotomous nature of the gender issues. Therefore, it is advisable to always interpret them considering the social hierarchies which cross the professions. In this manner, analyzing activities of services "typically female" marked by social devaluation and poor salaries, this research allowed one to verify the need for supplementary salaries, whether by other work contracts in the same profession, or by working in the informal market [2]. So, for these socially underprivileged women, their working days become extremely long and, in some cases, due to their housework, there is hardly any free time for themselves. These studies also highlight how the intense management of time - linked to the relational dimension of activities where various aspects need to be simul- 
taneously contemplated - ends up by reinforcing an expression of the gender relations, in a method of time management where priority is given to taking care of others, in detriment of the use of time for taking care of oneself and for leisure. Moreover, these are factors that seem to interfere in the health/illness process.

This reflection leads to a critical analysis of the referential for the training courses, in terms of organization of work schedules, endeavoring to overcome a defined formulation on the neutral masculine.

The other question relates to the "invested skills" of the trainees, both male and female, and the potential interference of their "motives" during the course of the training session. If it is granted that their experience and their knowledge of certain forms of work time management will foster the discussion on the "invested skills", and enrich the collective reflection on the definition of alternative ways, one should now consider the transformation through training of the individuals which will in the end be at stake. This will not be strictly cognitive: the trainees will necessarily mobilize their manner of thinking about the gender issues at work and outside it.

How will the discussion and the appropriation of some of the "constituted skills" run, if they are mediated by this dimension of high density in historical, social and cultural terms? Will the paradigm mobilized in the development of this training course maintain intact when integrating a gender dimension?

In this manner, the principles considered for developing a continuous training course are confronted with the difficult consideration of a variable (gender), inevitably involving personal life factors in the study. It is not, in effect, evident for ergonomics, aimed at changing the work and declining the means of intervention which "externalize" the diagnostics produced. If we choose, however, to consider that this provides a source of renewed questions on work in our contemporary societies, the monitoring of the training course will require much more attention and will justify, perhaps, a new controversy for the reference paradigm.

These are the theoretical and methodological assumptions that will lead the pursuit of the research with the effective implementation of a training course as a result of the work already done.

\section{References}

[1] B. Barthe, C. Gadbois, S. Prunier and Y. Queinnec, Trabalhar em horários atípicos, in: Ergonomia, P. Falzon, eds., Editora Blucher, São Paulo, Brasil, 2007, pp. 97-110.

[2] J. Brito, Trabalho e saúde coletiva: o ponto de vista da actividade e das relações de género, Ciência \& Saúde Coletiva, 10 (2005), 879-890.

[3] J. Castelhano and S. Nogueira, Género e trabalho: o processo de inserção feminina em profissões tradicionalmente masculinas, Research Final Report, Centro de Psicologia da Universidade do Porto, 2011.

[4] M. Lacomblez, M. Bellemare, C. Chatigny, C. Delgoulet, A. Re, L. Trudel and R. Vasconcelos, Ergonomic analysis of work activity and training: basic paradigm, evolutions and challenges, in : Meeting Diversity in Ergonomics, R. Pikaar, E. Konongsveld and P. Settels, eds., Elsevier Ltd., 2007.

[5] M. Lacomblez and C. Teiger, Ergonomia, formações e transformações, in: Ergonomia P. Falzon, ed., Editora Blucher, São Paulo, 2007, pp. $587-601$.

[6] K. Messing, La santé des travailleuses. La science est-elle aveugle?, Editions du remue-ménage/Octarès, MontréalToulouse, 1998

[7] OCDE, Panorama des statistiques 2010, Paris, 2010.

[8] J. Piaget, La prise de conscience, PUF, Paris, 1974.

[9] J. Piaget, Réussir et comprendre (2e édition), PUF, Paris, 1992.

[10]Y. Quéinnec, Horário, Laboreal, 3 (2007), 90-91.

[11]M. Santos and M. Lacomblez, Que fait la peur d'apprendre dans la zone prochaine de développement ?, Activités, 4 (2007), 16-29. http://www.activites.org

[12] M. Santos and M. Lacomblez, O que faz o medo de aprender na zona de desenvolvimento proximal?, Laboreal, 3 (2007), 06-14.

[13]Y. Schwartz and L. Durrive, Travail \& Ergologie: entretiens sur l'activité humaine, Octarés Editions, Toulouse, France, 2003.

[14]R. Silvera, Temps de travail et genre : une relation paradoxale, in : Femmes, genre et sociétés, l'état des savoirs, M. Maruani, dir., La Découverte, Paris, 2005, pp. 265-272.

[15]C. Teiger, «Les femmes aussi ont un cerveau !». Le travail des femmes en ergonomie: réflexions sur quelques paradoxes, Travailler, 15 (2006), 71-130.

[16]F. Verdier, B. Barthe and Y. Queinnec, Organização do trabalho em turnos: Concentrando-se na analise ergonômica ao longo das 24 horas in: Night and shiftwork on a 24-h society, F.M. Fischer, C. R. C. Moreno and L. Rotenberg, eds., Editora Atheneu, São Paulo, Brasil, 2003, pp. 137-157.

[17]L. Vogel, La dimension de genre en santé au travail : Premiers enseignements d'une enquête européenne, B T S Newsletter, 18 (2002), 14-19.

[18]L. Vygotski, Pensée \& langage (3e édition), La Dispute, Paris, 1997. 